\title{
A TANULÁS AFFEKTÍV PSZICHOLÓGIAI NÉZŐPONTBÓL
}

\author{
GOMBOS KATALIN $^{*}$ - BÁNYAI ÉVA ${ }^{* *}$ - VARGA KATALIN ${ }^{* * *}$ \\ * az Eötvös Loránd Tudományegyetem Pedagógiai Pszichológiai Karának \\ doktorandusz hallgatója \\ gombos.kati@pr.hu \\ ** az Eötvös Loránd Tudományegyetem Pedagógiai Pszichológiai Kar \\ Affektív Pszichológiai Intézeti Központjának \\ egyetemi tanára \\ banyai.eva@ppk.elte.hu \\ *** az Eötvös Loránd Tudományegyetem Pedagógiai Pszichológiai Kar \\ Affektív Pszichológiai Intézeti Központjának \\ egyetemi docense \\ apik@ppk.elte.hu
}

\begin{abstract}
A tanulmány a pszichológiában lezajlott affektív forradalom föbb lépéseit összegzi. Ez az új megközelités a kognitiv és konativ mozzanatok mellett az affektív folyamatok fontosságát hangsúlyozza. Számos tanulmány kerül bemutatásra, amelyek az affektív folyamatok fontosságát igazolják. Körvonalazódik, hogy az affektív háttér alapvetően befolyásolhatja a megismerö folyamatokat: a figyelmet, emlékezetet, problémamegoldást, döntéshozást, stb. A kötödéselmélet keretében a tanár-diák interakció is elemzésre kerül. A szerzők két, a téma szempontjából fontos empirikus kutatásuk föbb eredményeit is összegzik: az egyik a szuggesztív tanáregyéniségek ismérveit, a másik az egyetemi hallgatók előadóikhoz fözödö archaikus érzéseit tárta fel.
\end{abstract}

\section{A tanulás hagyományos nézőpontból}

A tanulást a legutóbbi időkig nemcsak az utca embere, de a pszichológia is tisztán kognitív (megismerö) tevékenységként tartotta számon. A szakmai megközelítésekben - jórészt állatkísérletekre alapozva - behaviorista, majd kognitív nézőpontokból mutatják be a témakört. A behaviorista dogma képviselöi úgy gondolták, hogy a tanulás építőkövei a klasszikusan és operánsan kondicionált egyszerü aszszociációk. Szerintük a tanulás alaptörvényei az állatokra és az emberre egyformán igazak. Vizsgálták, hogy a jutalmazás és a büntetés miként befolyásolja a tanulási folyamatokat. A hangsúly a külső ingerekre és válaszokra tevődött, hiszen a viselkedést inkább külső, mint belső mentális okok következményeiként magyarázták. A kondicionálás és föleg a komplex tanulás megértéséhez azonban figyelembe kellett venni, hogy az élőlény milyen előzetes tudással, elvárással rendelkezik az inge- 
rek és a válaszok kapcsolatairól, sőt, hogy viselkedése milyen célokat, tendenciákat követ. Tehát a figyelem a közvetlen tapasztalatok hangsúlyozásáról egyre inkább kognitív nézőpontokra irányult (Atkinson et al., 1995). Tanulmányunk arra kívánja felhívni a figyelmet, hogy a tanulás minősége vagy mennyisége nem csak a jutalmazástól és büntetéstől, illetve a gondolkodás és az értelmi képességek fejlettségétöl függ, hanem az ezekkel szorosan összefonódó affektív folyamatoktól is.

A pszichológia, az antikvitásban gyökerező kezdetei óta, a tudás, az akarat és az érzelem megértésére törekedett, de a tudomány egyenlötlen fejlődése miatt másmás került előtérbe (Hilgard, 1980). A 20. századi pszichológiai kutatások fő tárgya egyrészt a konáció, az akarat, hiszen a behaviorizmus képviselői föleg a motivált, célorientált tevékenységet kutatták, másrészt a hüvös, érzelemmentes megismeréssel, a gondolkodással, a kognícióval, a kognitivizmus foglalkozott (Forgas, 2001). Tehát a tudományos pszichológiában az affekció sokáig méltatlanul elhanyagolt területnek számított.

\section{Affektív forradalom}

\section{Az affektiv jelenségek kutatása}

A hosszú elhanyagolás után az érzelmek kutatásának új hulláma jelent meg visszacsapásként, válaszként az addigi „kognitív forradalom”-ra. A folyamat lendülete és hatásának mértéke alapján nem túlzás ,affektív forradalom” néven emlegetni ezt a korszakot (Pataki, 2004).

Az 1970-es évektől sorra jelentek meg kísérleti bizonyítékok az érzelmek és hangulatok kogníciót, döntéseket és viselkedést befolyásoló hatásáról (Atkinson et al., 2005). Az affektív jelenségek kutatására közvetlen befolyást gyakorolt az evolúciós pszichológiai paradigma kialakulása is (Barkow et al., 1991; Buss, 1995/2001). Az idegtudomány fejlődésével megjelent az affektív idegtudomány (Panksepp, 2004), s ma már a legkülönfélébb affektív jelenségek idegélettani hátterét ismerjük. Az affektív idegtudomány integratív természetü eredményei és az érzelmek egyre intenzívebb vizsgálata által nyújtott bizonyítékok ma már a pusztán kognitív megközelítésnél teljesebb képet nyújtanak az emberi viselkedés háttértényezőiről.

\section{Útban az affektiv tudomány kialakulása felé}

A tudományos ismeretek felhalmozódása nyomán szükségszerủen új paradigma született, kialakult az affektív tudomány. A pszichológiában tapasztalható szemléletváltással párhuzamosan különféle rokon területeken, így a társadalomtudományokban és embertudományokban, s ezeken belül például az antropológia és a szociológia területén szintén dinamikus fejlődés mutatkozott az affektív jelenségek kutatásában. 
Az új szemlélet tudományos érvényesítésének, művelésének „kellékei” sorra jelentek meg a különböző affektív kutatások közti információcsere és integráció elősegítésére. 1984-ben megalakult az Érzelmek Kutatásának Nemzetközi Társasága (International Society for Research on Emotions). Monográfia-sorozat (Series in Affective Science) indult az affektív tudomány köréhez kapcsolódóan Davidson, Ekman és Scherer szerkesztésében. Interdiszciplináris folyóiratok indultak útjukra: Emotion; Emotion and Cognition; Consciousness and Emotion, melyek szintén az affektív folyamatokkal foglalkoznak. Mára az affektív jelenségek tudományos vizsgálata a pszichológia legdinamikusabban fejlődő területének tekinthető.

\section{Az affektív tudomány kibontakozása}

Az affektív tudomány kibontakozását mutatja, hogy Davidson, Scherer és Goldsmith szerkesztésében 2003 megjelent az affektív tudományok kézikönyve (Handbook of Affective Sciences), amely az affektív jelenségek területén összegyült modern kutatási adatokat foglalja össze. Bevallott célja az affektív tudomány formális zászlóbontása (Davidson et al., 2003).

Az affektív tudomány mai helyzete a tudomány multidiszciplináris területeinek korai napjaira emlékeztet, hasonlít a kognitív tudománynak az 1960-as évek végére kialakult helyzetéhez. Neisser Kognitív pszichológia (Cognitive Psychology) címü könyvének megjelenése (1967) előtt sok - Neisser által prototipikusnak tekintett kognitív pszichológus - nem tekintette magát kognitív pszichológusnak, csak Neisser könyve segített fókuszálni, integrálni és katalizálni a területet, ami azután az akadémikus pszichológia vezető területévé vált. Davidson, Sherer és Goldsmith említett kézikönyve hasonló szerepet játszik az affektív tudomány területén.

\section{Az affektív tudomány tárgya}

Az affektív tudomány nem csupán az érzelmek tudománya. Sokkal szélesebb jelenségkört ölel fel. A hat leggyakrabban tanulmányozott affektiv jelenség: az emóció (érzelem); az érzés, érzet (feeling); a hangulat; az attitüd; az affektív stílus; és a temperamentum. Az affektív jelenségek között vannak részleges átfedések, azaz ezek nem ún. ortogonális konstruktumok. Erre, mindannyiunk által megtapasztalható példa, hogy ellenséges hangulatban nagyobb valószínüséggel élhető át a düh. Az affektív jelenségek megkülönböztetése nem jelenti azt, hogy szükségképpen eltérő neurális szubsztrátumuk van. Például a félelem megjelenésének hátterében álló idegi kör egy része a szorongó hangulat vagy az affektív stílus kialakulásában is közremüködik.

Az affektív jelenségeket időtartamuk szerint is meg lehet különböztetni egymástól (Oatley és Jenkins, 2001). Az érzelmek olyan állapotok, amelyek csak korlátozott ideig tartanak, amelyeknek az ember tudatában van, be tud számolni róluk, ilyenek például a pár másodpercig tartó arckifejezések, testi válaszok. A hangulat 
olyan állapot, ami órákig, napokig, hetekig tarthat, de nehéz meghatározni a kezdetét, a végét. Míg az érzelmi epizódoknak van tárgyuk, a hangulatoknak nincs. Lehet a hangulatunk például vidám vagy szomorú. Változtatni tudunk az irányán akaratlagosan is. Hetekig, hónapokig vagy évekig is elhúzódhatnak az érzelmi zavarok. A leggyakoribb ezek közül a hangulatzavar, a depresszió, a mánia és a szorongás. Vannak élethosszig tartó vonásaink, amelyeknek érzelmi összetevői is vannak. Ilyen például a félénkség, mint a társas szorongásra való hajlam.

\section{Az affektiv forradalom a pszichológiában}

Az affektív tudomány zászlóbontása világossá tette: „affektív forradalom” zajlott le a pszichológiában. Felismerték az affektív folyamatok jelentőségét az egyén erőforrásainak mozgósításában, ami szükséges a váratlan helyzetekkel való megküzdéshez, a büntetés elkerüléséhez, a jutalom, gyönyör elnyeréséhez. Továbbá fontos a társas interakciókban, a szaporodás sikerében, a személyiség fejlódésében, a csoportfolyamatok szabályozásában, az egészség megtartásában, a betegségből való felgyógyulásban. Az affektív forradalom hatására az affektív jelenségek új szemlélete került be a pszichológiába. Felhívta a figyelmet arra, hogy az érzelmi válaszok a társas környezettel való megküzdés hasznos, sőt alapvető eszközei. Az új szemlélet hatására az érzelmi jelenségek a pszichológiai elméletalkotás perifériájáról a középpontba kerültek.

\section{A kognitiv, az affektiv és a motivációs rendszer}

Az affektív forradalom hatására egyre többen és egyre differenciáltabban foglalkoznak az érzelem és a megismerés közti bonyolult, kontextus-érzékeny és interaktív kapcsolattal (Forgas, 2000; Oatley és Jenkins, 2001; Atkinson et al., 2005). A következőkben csak néhány témára utalunk.

Pszichopatológiai jelenségek jelzik a kognitív, az emocionális és a motivációs hatások összefüggéseit. Igy például az alexithymia, amely az emóciók kognitív feldolgozásának a deficitje. Az e problémában szenvedők nem képesek kifejezni, felismerni az érzelmeiket (Pataki, 2004).

A kognitív és affektív szabályozás összefüggéseiről ma már a legkülönfélébb idegtudományi bizonyítékok állnak rendelkezésünkre. Bizonyossá vált, hogy az affektív és a kognitív szabályozás agyi szubsztrátumai szorosan összefüggnek (Damasio, 1996; Panksepp,1989; Gazzaniga, 2000; Oatley és Jenkins, 2001). Széles körben vizsgálják például az amygdala szerepét az integrációban. Egy neuroanatómiai rendszer sérülése következtében magatartási változások alakulnak ki, amelyek olyan mintázatot mutatnak, ami jellemző az adott helyre vagy rendszerre, és egyaránt érintik a magatartás mindegyik dimenzióját, a kognitiv, az emocionális és a végrehajtó funkciót. A jobb agyféltekei agyvérzéseknél, például mindhárom szférában megje- 
lenik a deficit: a betegeknek gondjuk van a téri-vizuális tájékozódásban, érzéketlenek mások érzelmi kifejezéseire, romlik a döntési és tervezési képességük.

A kutatások nyomán az utóbbi tíz, tizenöt évben kialakulóban egy integrált kognitiv-affektív-motivációs rendszer felfogás (Spaulding, 1994; Forgács, 2001).

\section{Affektív forradalom a pedagógiában is?}

A pedagógiában egyre gyakrabban emlegetik az érzelmek és a motiváció szerepét a kompetencia alapú és az élethosszig tartó nevelés, oktatás kapcsán. Mégsem mondhatjuk még, hogy az affektív forradalom itt is átfogó változást hozott volna. Ezért is érdemes szemügyre venni, hogy milyen területeken, hol és hogyan is hatnak az affektív folyamatok.

A pedagógiai helyzet mindkét résztvevőjénél lényegesek az affektív folyamatok: ezekre építve hat a tanár, és ezen affektív folyamatok hatnak a diákra is. A tanár eredményességét befolyásolják az affektív tényezők. A hatékony tanár az érzelmeivel hat az érzelmekre: diákokéra, szülőkére, kollégáira. A tanulók oldaláról nézve pedig kijelenthetjük, hogy a diákok tanulási teljesítményét az affektív folyamatok is befolyásolják. Érzelmeik, hangulataik meghatározzák tanulási kedvüket, motivációjukat, kíváncsiságukat, tudásvágyukat. Ezen kívül vannak olyan tartós és részben öröklött személyiségvonások, képességek, amelyeknek egy részét az érzelmi intelligencia összetevőihez soroljuk, s amelyek szintén befolyásolják, hogy a tanulót az iskolában sikerek vagy kudarcok érik-e. Először a tanári szerep szempontjából, majd a tanulók szemszögéből tekintjük át az affektivitás jelentőségét, szerepét.

\section{A tanár hatékonyságát befolyásoló affektív tényezők}

\section{Az affektiv hatások érvényesülése a nevelés területén}

Az iskolában az oktatás és a nevelés szorosan összekapcsolódik. Mindkét tevékenység egyformán fontos. A gyermekek az iskolában nemcsak a tananyagot tanulják meg, hanem tanulnak viselkedési szabályokat, normákat, elsajátítanak értékeket is. A nevelés értékátadás.

Kelman (1973) megállapította, hogy a nevelés úgy értelmezhető, mint szociális befolyásolás. A szociális befolyásolásnak három szintjét írta le: behódolás, azonosulás vagy identifikáció és interiorizáció. Az azonosulás modellkövetés, utánzás révén jön létre. Alapja mindig valamilyen érzelem, ami lehet szeretet vagy félelem. Az azonosulás, identifikáció egyik magyarázata Freudtól (1923/1971) származik. A pszichoanalízis megteremtője szerint a felettes én - ami a személyiség azon struktúrája, ami ideáltörekvéseket, normákat és morális követelményeket tartalmaz úgy alakul ki, hogy az identifikációs folyamatok révén a tekintélyszemélyek által 
közvetített szabályok és normák belsővé válnak. Az identifikáció által vezérelt diák úgy cselekszik, hogy a nevelő elégedett legyen. Hatékony pedagógusnak az nevezhető, akinek befolyása az azonosulás, sőt az interiorizáció szintjére emelkedett (Ungárné, 1973). A tanuló tehát azt a tanármodellt követi leginkább, akihez érzelem köti. Más szóval a nevelés elöfeltétele az affektív kötelék, a kötödés.

\section{Korai kötődés}

A kötődés az ember számára alapvetően fontos veleszületett, az állati kötődéshez hasonlóan, személyhez való közelkerülést kereső, közelséget előidéző viselkedés (Bowlby, 1969). Az embernél viszont ennél többről van szó. Az embernél a kötődési kötelék olyan affektív kötelék egy személy és egy másik specifikus személy között, amely tartós és még a szeparáció alatt is megmarad (Bowlby, 1979; Ainsworth, 1982).

Harlow (1958) kísérletileg, empirikus adatokkal igazolta a kötődés meghatározó szerepét a világ felderítésének képességében. A kutató újszülött rézusz majmokat választott el az anyjuktól. A kismajmok számára a túléléshez elegendő feltételeket biztosította. Egy drótból készített és egy szőrmével burkolt műanyát tett a kismajmok ketrecébe. A drótanyára cumisüveget erősített, amelyből képes volt táplálkozni a kismajom, a szőranyán nem helyezett el táplálékforrást. A rézusz majmok az idejük nagy részét mégis a szőranyán töltötték, sőt ha valamilyen félelemkeltő tárgyat helyeztek a kis állatok közelébe, akkor a szőranyához futottak, ott találtak megnyugvást, biztonságot. Idegen környezetbe kerülve, csak akkor kezdték felfedezni az újdonságokat, akkor próbálgatták ki a játékokat, tárgyakat, mikor jelen volt a biztonságos bázis, a szőranya (Harlow, 1950). A világ felfedezésének, a környezet megismerésének alapfeltétele tehát a megfelelő kötődés, a biztos érzelmi háttér.

Butler (1958) kísérletében a majmok a tömör falú ketrecükön lévő kis ablak kinyitásával juthattak újszerü ingerhez. Maga az inger látványa önmagában jutalmazó volt az állat számára. Az állatot jobban érdekelte, ha a fajtársát láthatta az ablak mögött, mint ha például gyümölcskosár volt számukra kihelyezve. Ha viszont félelemkeltő ingert - kutyaugatást, anyjától elszakított majomkölyök visítását „talált" a kísérleti állat a ketrecen kívül, alig-alig merte kinyitni az ablakot. A felfedezés, a kíváncsiság kielégítésének élményét felváltotta a félelem. A szorongás gátat szab a világ megismerésére törekvő kíváncsiság kibontakozásának.

A korai állatkísérletek felvetették tehát, hogy a korai kötődés olyan erős érzelmi kötelék, ami nem csak pillanatnyi szükségletünk, de a későbbi fejlödésre is jelentősen kihat.

Ainsworth és munkatársai (1978) a jelenségkört humán területen vizsgálták. Idegen helyzetben figyelték meg 12 és 18 hónap közti kisgyermekeket. Az anya a gyermekkel egy erre a célra berendezett idegen helyre ment, ahol játékokat helyeztek el. A teremben már egy idegen felnőtt is várakozott. A kisgyermekek - általában - anyjuk jelenlétében elindultak környezetük felfedezésére, elkezdtek ját- 
szani, majd az anyjuk távozásával azonnal abbahagytak minden tevékenységet, és sírva az ajtóhoz másztak, tipegtek. Témánk szempontjából kulcsmozzanat, hogy a gyermek csak akkor indul el felfedezni a környezetét, akkor mer elszakadni az anyjától, ha biztonságban érzi magát, biztonságosan kötődik. Fontos, hogy legyen kitöl elindulni és kihez visszaérkezni. Az önállóan indított manipuláció, az önálló játék közben szerez tapasztalatot a gyermek a világról és önmagáról. Piaget (1992) rendszerében egyértelmü, hogy az összetett értelmi folyamatok megalapozója a szenzomotoros fázisban szerzett tapasztalat, amelynek gazdagságát alapvetően befolyásolja tehát a korai életszakasz affektív töltete. Csakis biztonságos környezetben képes a gyermek, az ember tanulni, ismereteket szerezni, új képességeket elsajátítani, csakis stabil érzelmi kötelék ad alapot a harmonikus személyiségfejlődésre.

\section{Idegtudományi bizonyítékok}

Idegtudományi bizonyítékok is megerősítették a korai kötődés fontosságát. A központi idegrendszer fontos ingerületátvivő anyagainak, a noradrenalinnak, a dopaminnak és a szerotoninnek a mennyisége és aránya az anyától és társaitól - életük korai szakaszában - elválasztott állatoknál másképp alakul, nem olyan stabil, mint a normál társas környezetben nevelt állatoknál. A szociálisan deprivált állatoknál emellett a kérgi és kisagyi idegsejtek dendrit-elágazódása csökken, a limbikus rendszer és a kisagy EEG-je változik, ami úgynevezett denervációs szuperszenzitivitáshoz vezet (Kraemer és Clark, 1990).

A noradrenalin és dopamin rendszer izoláció okozta deficitje kritikus, mert normálisan ezek a rendszerek posztnatálisan tovább fejlödnek és összefüggésben vannak a stresszorokra adott figyelemmel és reakciókkal, a cirkadian ritmussal és a neuronális plaszticitással. Kraemer (1992) különféle kísérleti körülmények között nevelt rézuszmajmok kötődési viselkedését vetette össze a gerincvelői folyadék noradrenalin koncentrációjával. Egyre kedvezőbb társas feltételeket teremtett a kismajmoknak: drótanya, majd szőranya, élő kortársak, élő anya társaságában nevelte azokat. Azt találta, hogy amint kedvezőbb társas közeg veszi körbe a kismajmot, a kötődési viselkedés ugyan egyre erősebb lesz, ennek a fontos ingerületátvivő anyagnak a mennyisége viszont nem nő jelentősen. Csak a felnőtt élő pótanyával nevelkedetteknél mutattak ki jelentős növekedést a cerebrospinális noradrenalin koncentrációban, a különféle mủanyák, a megfelelő fizikális ellátás ellenére sem váltották ki ezt a hatást. Objektív, megfogható bizonyítékot találtak tehát arra, hogy a szociális depriváció, a szociális környezettől, az anyától való megfosztottság idegrendszeri problémákat okoz, ami az egyedfejlődést megzavarhatja.

Az ember társas lény

Nemcsak az anya - gyermek kapcsolat fontos. Field érzékletesen fogalmazza meg, hogy kötődéseink egész életünk során meghatározóak: ,,... a kötődési kapcsolat egy 
optimális növekedési állapotot facilitál, amit az egyének vagy kapcsolatuk változása, vagy elválásuk, szeparációjuk és a nyomában bekövetkező viselkedéses és fiziológiai dezorganizáció veszélyeztet. Tehát a kötődések pszichobiológiailag adaptívak a szervezet szervezettsége, egyensúlya és növekedése szempontjából. Mivel a szervezet viselkedésrepertoárja, fiziológiai állapota és növekedési szükségletei integrált többváltozós komplexumot képeznek, ami a fejlődéssel változik, az élet során több különböző kötődéseket élünk át." (Field, 1985, 415-416. o.)

Életünk további kapcsolatai majdnem ugyanannyira fontosak lehetnek tehát, mint a korai gyermekkorban az anyával való kapcsolat. Ma már számos bizonyítékunk van arra, hogy az élet fontos kapcsolatait fenntartó pozitív érzelmek, a szeretet, a szerelem és a gyerekkori kötődés funkcióikban, dinamikájukban és típusaikban azonosak. A szeretethez vagy a szerelmi kapcsolathoz ugyanaz a funkció társul: közelségkeresés, a szeparáció elkerülése. A későbbi kapcsolatok is biztos bázist jelentenek, ahonnan elindulhatunk felfedezni a világot. Egy jó barát, egy társ „biztos mennyországot” jelenthet, ahol megnyugodhatunk (Weiss, 1982). Dinamikájuk is azonos, mert ha a kötődési személy hozzáférhető és érzékeny, akkor biztonságban érzi magát vele az ember, szeret és bízik magában. Ha viszont a félelem, szorongás uralja a kapcsolatot, akkor a késői kapcsolatokra is jellemző az ambivalens kötődés. Ha az állandó védekezés van előtérben a kapcsolatban, akkor az elkerülő kötődés lesz a jellemző.

Más empirikus vizsgálatok (Hazan és Shaver, 1987) is alátámasztják, hogy a kötődési típusok azonosak. Figyelemreméltó, hogy az embernél a romantikus szerelem, illetve az anyai szeretet átélésekor egymást jelentősen átfedő agyi területek aktívak, s e területek fontos képviselöi az agyi jutalmazó rendszernek (Bartels és Zeki, 2004; Zeki, 2007).

Az előzőekben bemutatott kutatási eredmények fényében érthetővé válik, hogy egyes tanárokhoz füződő érzelmi kötelék hasonló lehet ahhoz az érzéshez, amit a szüleinkkel kapcsolatosan érzünk.

\section{Tanárok, akik az érzelmeikkel hatnak az érzelmeinkre}

\section{A tanárok iránti archaikus - affektív - bevonódás}

Életünkben mindannyian találkoztunk már olyan tanárokkal, akik közel álltak és talán még ma is közel állnak hozzánk, akik meghatározó szerepet játszottak életünkben. Úgy emlékszünk az ilyen tanáregyéniségekre, hogy az órán nem lehetett nem rájuk figyelni, szívesen tanultuk a tantárgyukat, jól éreztük magunkat az óráikon. Az ilyen tanárok a jövőben is meghatározó szerepet játszanak személyiségünk fejlődésében, attitüdjeink, nézeteink formálásában. Szuggesztív szavaikra, gesztusukra évtizedek távlatából is emlékszünk, kritikus helyzetekben felidéződik egy-egy odavágó mondásuk, jellegzetes megnyilvánulásuk, hatásuk befolyásolja döntéseinket, cselekvésünket (Bányai et al., 2001). 
Bányai és munkatársai (2001) vizsgálták, hogy milyen jelenség állhat a szuggesztív egyéniségek hatásának hátterében. A kutatásban nyolc tanár egyetemi előadása után 454 hallgató töltötte ki a korai kötődési minták késői megjelenésére érzékeny ún. archaikus bevonódási skálát. Az archaikus bevonódás fogalmát Shor (1962/2008, 1965) vezette be a hipnózis szakirodalmába. Az archaikus bevonódás attól függ, hogy milyen archaikus tárgykapcsolatra hasonlító érzésvilág alakult ki a hipnotizőr személye iránt. Mennyire érzi tehát a helyzetet, a hipnotizőrrel való kapcsolatát a páciens olyannak, mint egy anya, apa, testvér - gyerek kapcsolatot. Az archaikus bevonódás mérésére Nash és Splinler (1989) dolgozott ki egy egyszerü papír-ceruza tesztet (ABS). Ezt a tesztet Bányai és munkatársai (2001) - amint fent jeleztük - tanárokra, előadói helyzetre alkalmazták, hiszen azt akarták megtudni, hogy mi a titka egyes tanáregyéniségeknek, hogyan tudják befolyásolni egyes tanárok a diákjaikat. Faktoranalízissel három faktor volt elkülönithetö: 1. Csodálat és kötődés. 2. Félelem a negatív megítéléstől. 3. Függőségigény. Tehát a megkérdezett személyek egy része csodálatot érez a tanár iránt, és kötődik hozzá, többen azért figyelnek az előadó tanárra, mert félnek, hogy negatív megítélésben részesülnek, mások annyira kötődnek a tanárhoz, hogy úgy érzik magukat, mint a gyermek szüleihez való viszonyában, azaz függőséget éreznek. A kutatások eredményei szerint ugyanolyan magas lehet az archaikus bevonódás a tanárok iránt, mint hipnotizörök iránt csoportos helyzetben.

Következésképpen kimondható, hogy az egyén társas hatékonyságának is jó mutatója lehet, hogy kire milyen szintủ archaikus bevonódással reagál a személy. Mérei Ferenc (1988) szerint a vezetőknek van egy olyan tulajdonsága, amivel hatást tudnak kifejteni másokra, felkeltik, fokozzák az azonosulási feszültséget, indulati állásfoglalásra késztetnek, hasonulást, azonosulást sugallnak. Ezt, a vezetőkre jellemző tulajdonságot Mérei Ferenc társas penetranciának nevezte. A szuggesztív tanárok is a legősibb érzelmeinkre hatnak, a legjelentősebb érzéseket váltják ki belőlünk.

\section{Szuggesztív tanáregyéniségek}

Ha egy jó tanárról beszélünk, a szuggesztív jelzőt használjuk. Bár sokan alkalmazzák ezt a kifejezést, mégsem találhatunk tudományosan megfogalmazott pedagógiai vagy pszichológiai meghatározásokat e tulajdonságról. A következőkben egy olyan vizsgálatot mutatunk be, amelynek éppen az volt a célja, hogy meghatározza, körülhatárolja a szuggesztív tanároknak tulajdonított eszközöket vagy tulajdonságokat.

A fogalom körvonalazására készült kérdőív (Kissné, 2008) 115 eleme tulajdonságokból, állításokból tevődött össze. A tulajdonságlista a szakirodalomban előforduló hatékony tanárra vonatkozó tulajdonságokból, és a kutatás hipotéziseiben megfogalmazott feltételezések szerint állt össze. A tulajdonságok véletlenszerü elrendezésben kerültek a kérdőívbe. A válaszadónak ötpontos skálán kellett érté- 
kelni a tulajdonságokat, aszerint hogy azok mennyire jellemzőek választott szuggesztív tanárára. A vizsgálatban 325 fó vett részt: 213 pedagógus és pedagógushallgató, 19 éves kortól vegyes korcsoport; 112 nem pedagógus, minimum középfokú végzettségü, 19 évesnél idősebb személy, a nők aránya közel hatszorosa volt a férfiakénak.

A kutatás hipotézise az volt, hogy valószínúleg kiugrik valamelyik tulajdonság- vagy képességcsoport a többi közül, amivel leginkább meghatározható, hogy miben áll a pedagógus szuggesztivitása. Elvárható volt olyan faktorok keletkezése, amelyek a kommunikációs képességeket, személyiségjegyeket, vezetői vagy más interperszonális képességeket, és/vagy a szakmai kompetencia elemeit foglalják össze. A hipotézisek egy része beigazolódott, de a faktorok másként alakultak, érdekesebb képet mutattak a vártnál.

A statisztikai adatelemzés, a faktoranalízis során a tulajdonságok három nagy csoportba rendezödtek. A szuggesztív tanárokat a következö stílusok jellemzik: 1. az érzelmi fókuszú vagy anyai stílus; 2 . feladatfókuszú apai stílus; 3. tekintélyes, autokrata apai stílus. Az eredmények párhuzamba vonhatóak azzal a tulajdonságlistával, amit Bagdy (1994) írt le a tanulók és szülők elvárásai alapján optimálisnak tartott pedagógiai képességek felsorolása kapcsán. Megemlíti, hogy a tanárnak gyakran eszményítő elvárásrendszernek kell eleget tennie. Az atmoszféra, a biztonságteremtés képességét, a megértő magatartást, a magas fokú intelligenciát, valamint a jó apai és jó anyai képességek meglétét emeli ki.

A kutatási eredményekhez kapcsolódóan témánk szempontjából néhány fontos következtetést mutatunk be. A nők számára fontosabb, hogy érzelmileg kötődjenek a pedagógushoz, illetve a pedagógus az érzelmeiken keresztül hasson rájuk, az érzelmeiket célozza meg. A férfiak számára a katonás tekintély a fontos. Illetve azok a tulajdonságok kerültek még ide, amelyek a különc, tudóstípusú előadót jellemeznék. Figyelemfelhívó, hogy a második faktor, a kompetencia, a hitelesség, a szaktudás mindenkiben tiszteletet, elismerést ébreszt. Annak, hogy a nők inkább választották az anyai, a férfiak az apai típust, akár a nemi identitás kialakulásában, vagy megerősítésében is lehet jelentősége. Az érzelmi faktor, az anyai faktor fontosabb, mint a tekintéllyel összefüggő faktor, ami azt jelentheti, hogy nagyon nagy jelentösége van a tanártól jövő szeretetnek, elfogadásnak. Ennek a típusnak a választása a rogersi elfogadó, humanisztikus pedagógust idézi. A tekintély is nagyon meghatározó lehet. A kérdőíves kikérdezéshez kapcsolódó szóbeli beszámolójukban sokan nagytekintélyü tanárokat említettek, akik szigorúak voltak. Gyakran arról beszéltek egyes válaszadók, hogy megbuktatta őket a tanár a tantárgyából, mégis őt tisztelte leginkább. Ez a fajta tanártípus a freudi elhárító mechanizmusokra is utalhat. A félelem, szorongás csökkentése miatt az egyén azonosul az agresszorral (Freud, 1923/1971). Ezen kívül lehet, hogy a tanár reális értékelését tisztelték a megkérdezettek. A szuggesztivitás lényegét igazolni látszott az, hogy a hipnotizőr tulajdonságaival találunk összefüggést. Az anyai hipnotizőr stílussal és az ellentmondást 
nem türő, apai tekintélyre építő hipnotizőr szerepével is összhangban van ez az eredmény (Lásd fenn: Bányai et al., 2001; Bányai, 2008). A legtöbbször választott tulajdonságok a „szereti a diákjait” és a „szereti a tárgyát” állítások voltak. A szeretet, kötődés fontossága a nevelésben objektív számadatokkal is alátámasztható. A szuggesztív tanár az érzelmeinkre hat leginkább, és igen erős modellt, azonosulási mintát jelent (Kissné, 2007).

\section{Érzelmekre ható oktatási módszerek}

A tanár nevelési-oktatási módszerei is meghatározóak a tanulók tanulási kedvének alakulásában és abban, hogy milyen eredményeket érnek el. Rutter és munkatársai (idézi Cole és Cole, 1998) azt találták középiskolák összehasonlító vizsgálata során, hogy azok a legsikeresebb, a legjobb eredményeket felmutató osztályok, ahol a tanár viselkedésmódját inkább a jutalmazás, mint a büntetés jellemezi. A jutalmazást is szakszerủen, átgondoltan kell azonban alkalmazni.

Tudjuk, hogy létezik külső és belső motiváció is ${ }^{1}$. Az extrinzik, vagy külső motiváció jutalmakkal vagy büntetésekkel kívülről irányítható, míg az intrinzik, vagy belső motiváció az emberek személyiségéből fakadóan létezik (Deci, 1971). Ha eleve magas az embernek az érdeklődése, akkor a jutalom bevezetése a belső motiváltságot csökkenti (Deci et al., 1999). Deci $(1971,1975,1980)$ számos kísérlettel bizonyította ezt a tényt. Deci és munkatársai által végzett, klasszikussá vált vizsgálatokban a kísérleti személyek belső motivációját jutalmazással külső motivációra fordították (Deci et al., 1985, 1987, 1994, 2000). Élvezetes, külső megerősítés nélkül végzett cselekvést (például keresztrejtvényfejtést) pénzzel jutalmazva az érdeklődés, a belső motiváció kimutathatóan alábbhagyott. A jutalmazás leszoktathatja az egyént arról, hogy saját cselekvései eredményét jutalomként élje át, ugyanakkor rászoktathatja arra, hogy a ,jót" mindig kívülről várja. Ilyen esetben a jutalmazás nemhogy szükséges, hanem ártalmas is lehet (Barkóczy, Putnoki, 1980; Ryan és Deci, 2000).

Egy cselekvés végrehajtása már önmagában jutalomnak tekinthetö. Az emberi agy megjutalmazza saját magát a teljesítményért, például azzal, hogy fokozott boldogságérzetet teremt. Így nem maga a cselekvés, hanem az azzal járó és azt követő érzelem lesz valójában a jutalom (Deci és Ryan, 1990).

Vannak viszont esetek, amikor a külső jutalmazással, tárgyi jutalommal is fenntarthatjuk az érdeklődést, ha azt váratlanul kapja az egyén. Isen (1978) kutatásai bizonyították, hogy az ilyen meglepetés mozgósítja a pozitív érzelmeinket, hatására az ember boldog lesz, ami kedvezően hat nemcsak a motivációra, hanem az attitüdökre, kognitív rendszerre is. A pozitív érzelmek kreatívabbá tesznek a problémamegoldásban.

\footnotetext{
${ }^{1}$ A motiváció, illletve a jutalmazás büntetés témájával kapcsolatban lásd még a kötetben Gordon Györi János, Katona Nóra, valamint Reinhardt Melinda és Kökönyei Gyöngyi tanulmányát.
} 
A gyermekek az iskolába nagyon nagy tudásvággyal, érdeklődéssel, kíváncsisággal érkeznek. Szerencsés esetben sikerül ezt az előrevivő belső szükségletet fenntartani. A kudarc csökkenti, a siker növeli a motivációt. Nagyon nagy felelőssége van a pedagógusnak abban, hogy biztosítsa, vagy segítsen abban, hogy minden egyes gyermek érjen el a maga területén sikert. A kompetencia megtapasztalása elörevisz, fokozza az önbizalmat, ami a gyermek későbbi életpályájára is kihat. A különféle pedagógiai módszerek közül tehát azok a pozitív módszerek szolgálják a tanulók belső érdeklődésének, tudásvágyának fenntartását, amelyek örömérzést okoznak.

\section{Az érzelmek hatása a meggyőzésben}

A nevelés, értékátadás során az idősebb diákokat a tanár leginkább akkor tudja befolyásolni, ha a kívánt érték, norma a tanuló saját értékrendjével összhangban van. Ekkor a szociális befolyásolásnak a legfelsőbb szintje, interiorizáció jön létre. A gyermek a normát, értéket - mivel azzal maga is egyetért - beépíti személyiségébe, belsővé válik a kívánt tartalom. Ehhez szükséges, hogy meg tudjuk győzni a tanulót az igazunkról (Kelman, 1973).

Quntillianus meggyőzésről szóló klasszikus tanításában azt mondja, hogy a védőbeszédben olyan fordulatokat kell használnunk, amivel érzelmeinket megértetjük a másikkal. Erre azért van szükség, hogy átérezhessék a döntésnél a bírák, hogy mi milyen helyzetben voltunk. A döntéshozó érzelmeit a lehetö legpontosabban kell kiváltatnunk. Szerinte a másokkal kapcsolatos interakcióban ki kell bővítenünk a korlátozott emberi képességeinket oly módon, hogy érzelmi heurasztikákat használunk (lásd Oatley és Jenkins, 2001). Úgy tünik tehát, hogy a meggyőzéshez érzelmekre ható szuggesztív kommunikációra van szükség.

\section{Szuggesztiv, érzelmekre ható kommunikáció az iskolában}

A szuggesztív kommunikáció lényege, hogy „önkéntelen válasz vált ki, amely válasz a kommunikáció gondolati tartalmát jeleníti meg" (Weitzenhoffer, 1989, 321. o.). A szuggesztiós hatást az különbözteti meg például a kérésre vagy a parancsra történő engedelmességtől, hogy a személyek közötti kommunikáció ${ }^{2}$ eredményeként automatizmus lép fel. A válasz tehát önkéntelen olyan értelemben, hogy sokszor nem is lehet tudatosan kontrollálni.

A szuggesztív „üzenetek” pozitívak és negatívak egyaránt lehetnek. A média negatív szuggesztiós hatása például, hogy túl vékony nőket állítanak ideálként elénk. Ennek következtében nagyon sok nö, köztük még serdülö gyerekek is fogyókúráznak, egyre nagyobb az evészavarban szenvedők, anorexiások, bulimiások száma (Hamilton és Waller, 1992).

\footnotetext{
${ }^{2}$ A kommunikáció kultúratanulás elméleti megközelítését lásd Gordon Győri János tanulmányában.
} 
Az iskolában is ismertek a negatív szuggesztiós hatások. Ilyen lehet például a Pygmalion effektus is. A tanár akár verbális, akár nem verbális jelekkel, értékeléssel vagy más módon sugalmazza, közvetíti, hogy milyen előfeltevései vannak a diákról, mit vár el tőle, milyen legyen az adott tanuló. A Pygmalion effektus pedagógiai folyamatban érvényesülö hatását Rosenthal és Jakobson írták le: egy iskola tanáraiban néhány gyerek iskolai teljesítményével kapcsolatban negatív elvárásokat alakítottak ki, ennek eredményeképpen a gyerekek tényleges osztályzatai romlottak a tanév végére. Az elvárások a tanulók intellektuális teljesítményére, magatartására és iskolai pályafutására is vonatkoztak (Cserné, 1991).

Természetesen a szuggesztiók pozitív hatásait is kihasználhatjuk az iskolában. Lev Tolsztoj már a 19. század. végén hangsúlyozta a szuggesztiók szerepét az oktatásban (Szabó, 1987). Figyelmét főleg az orvosi hipnózis és szuggesztió eredményei ragadták meg, $\mathrm{s}$ ezt a nevelés értelmezésében is érvényesítette: „A nevelés: a szívre való hatás a példa hipnózisa útján" (Tolsztoj, idézi Szabó, 1987, 132-133. o.). Nem új keletủ tehát a szuggesztiók alkalmazásának igénye az iskolában.

A pedagógiai módszerek repertoárját azért is lehetne bővíteni ezzel az eszközzel, mert a gyermekek általában jól szuggerálhatók, érzékenyek az érzelmi ragályra, nagy az utánzási hajlamuk (Zétényi, 2004). Körülbelül óvodás kortól tíz éves korig jelentős a gyermekek szuggesztibilitása, vagyis a szuggesztiókra való fogékonyság egyénre jellemző szintje (Mészáros, 1984).

Az orvosi gyakorlatban egyre szélesebb körben terjed a szuggesztiók alkalmazása. A gyógyulás érdekében az erre felkészített szakemberek a betegeknél pozitív szuggesztiókat alkalmaznak. Ezen a téren nagyon sok pozitív tapasztalatunk van, empirikus kutatások bizonyítják a módszer hatékonyságát (Varga, 2008). Kézenfekvő, hogy ha a reklámoktól kezdve a betegek gyógyításáig különféle terepeken alkalmazhatók a szuggesztív technikák, a módszer tudatos és szakszerü alkalmazására a pedagógiában is lenne lehetőség.

\section{A diák tanulási teljesítményét befolyásoló affektív tényezők}

Hogyan hatnak a tanuló affektív folyamatai, azaz érzelmei, hangulatai, a megismerésre irányuló motivációi és bizonyos személyiségvonásai tanulási teljesítményére?

\section{Az emóciók és a viselkedés kapcsolata}

Különböző felfogások uralkodtak az idők során a tudományban az emóciók és a viselkedés kapcsolatáról. A racionalista felfogás - például Platón - szerint az érzelmek a viselkedést dezorganizáló, zavaró elemek, az emberi élet primitív aspektusai. A biológiai nézet szerint az érzelmek inkább komplex jelenségek, késői teljesítmények, amelyek a biológiailag fontos helyzetekre való megbízható válaszokért felelősek. A fiziológiai felfogás (Grastyán, 1974/1988) szerint minden vi- 
selkedésnek van emocionális aspektusa, a kortikális és szubkortikális területek egyaránt fontosak az érzelmekben, az emocionális reaktivitás a fejlődés magasabb fokán jelenik meg. Az evolúciós pszichológiai felfogás (például Oatley és Jenkins, 2001; Forgas, 2000) azt hangsúlyozza, hogy az érzelmi válaszok a társas környezettel való megküzdésnek hasznos, sőt alapvető eszközei.

Az érzelmek, hangulatok hatása a megismerö tevékenységre: az érem két oldala

A pszichológia évtizedeken keresztül szinte kizárólagosan a negatív érzelmekkel foglalkozott. A pozitív érzelmek napjainkban kerültek elötérbe. Egyre többet hallunk a boldogság, a jó hangulat és a jó környezet pozitív hatásáról. Mára bebizonyosodott, hogy az érzelmek és a hangulatok a megismerö tevékenység minden formájára döntő hatást gyakorolnak

A hangulat hatását az észlelésre mutatta ki Niedenthal és Setterlund (idézi Oatley és Jenkins, 2001). Zenével szomorú, illetve boldog hangulatot idéztek elö, ezután a hirtelen felvillanó különböző érzelmekhez kapcsolódó létező és nem létező szavakat kellett szétválasztani. Általában gyorsabb döntéseket hoztak az emberek pozitív hangulatú szavak észlelésénél.

Az érzelmek hatnak a figyelemre. A félelem beszükíti a figyelmet, a hangulatkeltő ingerre koncentrál a szorongó ember, és arra, hogy kerülhet újra biztonságba. Ez a jelenség a túlélés szempontjából fontos, az evolúció során alakult ki (Oatley és Jenkins, 2001).

Az úgynevezett érzelmi Stroop teszten alapuló kísérletek támasztották alá ezt a tényt. Az klasszikus Stroop (1935) tesztben a piros, sárga, kék szavakat néha különféle színekkel nyomtatják: például kék tintával a „zöld” szót. A feladat a felvillanó szó nyomtatási színének meghatározása, függetlenül attól, mi a szó jelentése. A kísérleti személy válaszadásának reakcióideje megnő, ha eltérő a betük színe a jelentéstől. A szó jelentése ugyanis automatikusan megragadja és eltereli a figyelmet.

Az érzelmi Stroop-jelenség ezen klasszikus teszt affektív jelenségekre kidolgozott változata. A szóingerek ez esetben jelentős érzelmi töltésủ (például szorongáskeltő), illetve semleges szavak. A klasszikus helyzethez hasonlóan a feladat, itt is a látott szó színének megnevezése, a jelentéstől függetlenül. Az általános tapasztalat az, hogy a megterhelő szavak esetében - a színekhez hasonlóan - megnő a válaszidö, ami arra utal, hogy az érzelmi feldolgozás automatikusan zajlik, és ez bizonyos kapacitást köt le a kognitív rendszerben. Ez a jelenség annak ellenére bekövetkezik, hogy a feladat szerint egyáltalán nem kellene a szavak jelentésével tehát magával az érzelmi üzenettel - foglalkozni (Oatley és Jenkins, 2001).

Foa (idézi Oatley és Jenkins, 2001) kísérletében nemi erőszak áldozatainak erőszakkal kapcsolatos és semleges szavakat villantott fel. A kísérleti személyek reakcióideje a számukra jelentéssel bíró szavaknál, azaz az erőszakkal kapcsolatos szavaknál megnőtt. Ezt a kísérletet megismételték más pszichés problémával küsz- 
ködő és egészséges személyeknél. A reakcióidő a beteg csoportnál a problémát felidéző szónál, az egészségesnél a kiegyensúlyozott, jó hangulatú, pozitív szavaknál nőtt meg (Oatley és Jenkins, 2001).

Érzelmi töltésủ helyzetben többet gondolkodunk, a felkavaró eseményt többször felidézzük, többet ismételgetjük azzal, hogy elmeséljük másnak. Mivel az ismételgetés és a szervezés javítja a hosszú távú memóriából való információ előhívását, így nem meglepő, hogy az érzelmeink befolyásolják az emlékezést. Ha egy nagyon jelentős, intenzív élményt élünk át, az villanófényszerüen, élénk felvillanó fényképek formájában elő-előugrik. A Challanger ürrepülő felrobbanása vagy a Reagen elnök elleni merénylet után azt találták a kutatók, hogy a megkérdezett emberek intenzíven, részletekbe menően emlékeznek, nem csak az eseményre, hanem saját körülményeikre is. Ezek az emlékek azonban hosszú távon elveszítik intenzitásukat (Atkinson et al., 1995).

A szorongás, a stressz az emlékezést is befolyásolja. Mindenki ismeri azt a jelenséget, amikor a kisdiák felel, vagy az egyetemi hallgató vizsgázik, és annak ellenére, hogy sokat tanult, mégsem emlékszik semmire, leblokkol. Ilyenkor Holmes (1974) szerint a szorongás negatív gondolatokat idéz elő, például, hogy „,nem fogom tudni”, „nem értem” stb. Ezek a gondolatok interferálnak, vetélkednek a felidézendő anyaggal, megzavarva annak felidézését. Vannak azonban olyanok is, akiknél a teljesítmény éppen stressz helyzetben javul.

Bower (1981) klasszikus kísérletei felhívják a figyelmet arra, hogy az érzelmek a kontextushatás révén befolyásolják az emlékezetünket. Attól függően, hogy a kísérleti személyeknek pozitív vagy negatív hangulatot idéztek elö hipnózisban, boldog vagy szomorú életeseményeiket idézték fel könnyebben. Tanulási helyzetben is alkalmazták Bowerék (1981) ezt a vizsgálatot. A kísérleti személyeknél hipnózisban boldog vagy szomorú hangulatot idéztek elő, majd számukra két ember szomorú vagy boldog élettörténetét olvasták fel. A kísérlet után a kísérleti személyek a hangulatuknak megfelelő alakot gondolták a központi szereplőnek. Másnap a hangulatuknak megfelelő történetet tudták jobban felidézni, tehát ebből tanultak többet (lásd Atkinson et al., 1995).

Érzelmeink, akár pozitívak, akár negatívak befolyásolják ítéletalkotásunkat, döntéseinket is. A pozitív érzelmek többféleképpen. Egyrészt kreatívabbak leszünk a problémamegoldásban, döntésben, ahogy Isen (1978) fentebb említett kísérlete bizonyította, másrészt viszont elterelhetik a figyelmünket a logikai érvek elemzéséről, és hatásuk alatt a józan ítélőképesség veszíthet erejéből. Ezt az állítást olyan kísérletek támasztják alá, amelyekben a kísérleti személyeknél különböző jutalmakkal, vagy más módon jó hangulatot indukáltak. Az ezek után következő érvelés könnyebben megváltoztatta a boldog emberek addigi álláspontját, könnyebb volt őket befolyásolni.

Worth és Mackie (egy savas eső ellenőrzésére vonatkozó állítással kapcsolatosan mérte a kísérleti személyek egyetértésének vagy elutasításának fokát (lásd 
Oatley és Jenkins, 2001). Ezek után egy egyszerű feladat megoldásáért egy dollár jutalmat kapott a kísérleti csoport, a kontroll csoport nem kapott pénzt. A kutatók célja az volt, hogy jó hangulatot váltsanak ki a kísérleti csoportba tartozóknál. A feladatmegoldás után meghallgattak egy, a savas eső ellenőrzésének szükségességére vonatkozó előadást. A csoport egyik felének azt mondták, hogy az előadást egy környezetvédelem szakos egyetemi hallgató, azaz egy „szakértő” tartotta, a csoport másik fele viszont úgy tudta, hogy egy matematika szakos hallgató, azaz egy „,nem szakértő” előadását hallotta. A kísérleti személyeknek ezután ismét véleményt kellett mondaniuk a savas eső ellenőrzéséröl. A végeredmény: Semleges hangulatban nem volt hatással az attitüdváltoztatásra az, hogy a beszédet „,szakértö” vagy „nem szakérto”” tartotta, a jó hangulatú embereket viszont - ugyanazokkal az érvekkel - sokkal inkább meggyőzte az állítólagos szakértő. A boldogok tehát nem annyira mérlegelték, elemezték az érvek tényleges súlyát. Két évvel később egy hasonló vizsgálatot folytatott le a két fenti kutató, amelyben az egyik csoport két dollár jutalmat kapott, a másik semmit. A jutalomtól „megrészegült" kísérleti személyek, amikor hosszabb idő állt rendelkezésükre a döntésre, inkább tartották magukat az eredeti véleményükhöz, a másik csoportban nem volt ilyen különbség (Oatley és Jenkins, 2001).

Chaiken (1989) és munkatársai szerint kétféle út játszik döntő szerepet az érvek feldolgozásában. Ezek közül a jó hangulatban lévő személyek útlerövidítő, levágásos utat követnek (Petty és Cacioppo, 1986). Ez azt jelenti, hogy pozitív hangulatunk felszínes, figyelmetlenebb, a kommunikáció kevésbé lényeges aspektusaira adott válaszokat is megenged, például fogékony lehet az érvelést bemutató személy személyiségére vagy hírnevére, az érvelés érvényessége helyett. Ennek pozitív hatása lehet, ha gyorsan kell döntéseket hozni és feladatokat megoldani, akkor azonban, amikor mélyebb elemzésre van szükség, a negatív érzelmek pontosabb információfeldolgozást tesznek lehetővé. A pozitív érzelmek ugyanis megnyugtatnak minket azzal kapcsolatban, hogy „nincs veszély”, ezért viszonylag sematikus és heurisztikus, tehát felülről lefelé irányuló információfeldolgozásra indítanak. Ez teret ad az újszerü, kreatív megoldásoknak, míg a negatív érzelmek a problémákra hívják fel a figyelmet, és ezért aprólékosabb, külsőleg fókuszált és „feszes” kognitív stratégiákat mozgósítanak (Forgas, 2001).

A negatív érzelmek és hangulatok információfeldolgozásra gyakorolt pozitív hatását az alapozza meg, hogy specifikus válaszokra kényszerítenek bennünket. Ez azt eredményezi, hogy például a szociális ítéletalkotásban a negatív hangulatok megfontoltabb, a külvilág információit jobban figyelembe vevő információfeldolgozást eredményeznek (Forgas, 1991a, 1991b), figyelmesebben és motiváltabban dolgozzuk fel a külvilág releváns ingereit (Clark és Isen, 1982).

Az érzelmek megismerésre gyakorolt hatása egyrészt a megismerés tartalmát befolyásolja (mit gondolnak az emberek), másrészt a megismerés folyamatát is érintik (hogyan gondolkodnak az emberek). Forgács József „Affektus Beáramlási Modellje 
(Affect Infusion Model, AIM, összefoglalása: 2001) szerint az érzelembeáramlás mennyisége és valószínúsége a kognitív feldolgozó stratégiától függ. Azoknál a feldolgozási módoknál a legerősebb az érzelem beáramlása, amelyek heurisztikus feldolgozást igényelnek (egyszerü, személyesen kevéssé fontos feladatok), vagy pedig azoknál, ahol lényeges feldolgozás történik, azaz az embernek ténylegesen új információkat kell kiválasztania, megtanulnia vagy értelmeznie. A közvetlenül hozzáférhető információ, a túltanult, ismerős feladatok esetén és egy már meglévő cél érdekében szolgáló motivált feldolgozás esetén az affektusok kisebb szerepet játszanak a kognitív feldolgozásban. Mivel az iskolában érdemi információfeldolgozás történik, hiszen alapvetően új ismereteket sajátítanak el a diákok, az affektusoknak különösen nagy szerepük van az információ feldolgozásában.

A negatív és pozitív affektusok információfeldolgozásban betöltött szerepére vonatkozó fenti adatok, következtetések tükrében megállapíthatjuk, hogy az iskola világában ahhoz, hogy a diákokat egyrészt a külvilág ingereinek aprólékos, kontrollált és gondos feldolgozására késztessük, másrészt kreativitásukat is fokozzuk, az érzelmek és hangulatok teljes skálájára szükség van.

\section{Érzelmi intelligencia}

Seattle városában több iskolára kiterjedő egészségfejlesztési programon belül célul tűzték ki a gyermekek érzelmi és szociális képességeinek fejlesztését. Az eredmények azt mutatták, hogy a programban részt vevő iskolák tanulói később kezdték el a szexuális életet, körükben kevesebb nem kívánt terhesség fordult elö, mint más iskolákban. A gyermekek társas, érzelmi képességeinek fejlödése, azaz az érzelmi intelligencia fejlesztése állhat az empirikus adatok hátterében (Urbán, 2004).

Goleman vezette be a szakirodalomba az érzelmi intelligencia fogalmát. Az érzelmi intelligencia olyan képességeket foglal magában, mint „önmagunk ösztönzése, a frusztrációkkal dacoló kitartás; az indulat fékezése, a vágykeltés késleltetése; hangulataink kiegyensúlyozása, amely gátolja, hogy a bajban gondolkodásunk összezavarodjon; empátia és a remény." (Goleman 1977, 31. o.) Egyre több adat mutat rá, hogy az intelligenciahányadosból vagy az iskolai érdemjegyek átlagából nem lehet következtetni a későbbi életben elérhető sikerekre. A munkahelyeken, az üzleti életben, sőt az élet minden területén fontos saját érzelmeink szabályozása, mások érzelmeinek megértése, ami a társas világunkban való beválás kulcsa.

A tanár, ha rendelkezik megfelelő szintü érzelmi intelligenciával - az érzelmeket pontosan észleli és kifejezi, képes az érzelmekhez való hozzáférésre, azok mozgósítására, az érzelmek és az érzelmek „üzenetének” megértésére, az érzelmek szabályozására (Mayer et al., 2000) - akkor hatékonyabb pedagógiai munkát végezhet. Diákjaival kiegyensúlyozott kapcsolatot tud kialakítani, képes hatni rájuk, és képes az ö érzelmi intelligenciájuk fejlesztésére is. 


\section{Az érzelem és a tanulási motiváció kapcsolata}

Az érzelmek és motívumok szorosan összetartoznak. Hasonlítanak abban, hogy mindkettő aktiválja és irányítja a viselkedést, és emellett gyakran emóciók társulnak a motivált viselkedéshez. A tanulás szempontjából legfontosabb motívum a kíváncsiság.

\section{Kíváncsiság}

Az érzelmek, a hangulat befolyásolja a diákok tanulási képességeit. Sőt maga a tanulás is okozhat örömet, hiszen mindenkiben megvan a felfedezés, a kíváncsiság kielégítésének a vágya.

A kíváncsiság alapvető motívum a tanulásra, az ingerkeresésre. Már az állatok is bonyolult tevékenységeket végeznek kíváncsiságuk kielégítése érdekében. Nissen (1930) leírta, hogy kísérletükben a patkányok fájdalmas ingert (áramütést) is hajlandóak voltak elviselni azért, hogy egy olyan helyre mehessenek, ahol számukra ismeretlen, új tárgyat találtak. Butler (1966) kísérletben a majmok jutalmazás nélkül bonyolult tanulási feladatot hajtottak végre, csak azért, hogy a labor előterében kíváncsiskodjanak, új ingerekhez jussanak. Harlow és munkatársai (Harlow, 1950) olyan zárakat helyeztek el a rézusz majmok ketrecében, amelyeknek a kinyitásával nem szereztek meg semmilyen jutalmat. A kismajmok mégis órákon át foglalkoztak vele. A kutatók hat percenként visszaállították a szerkezetek eredeti állapotát, mégsem hagytak fel az állatok a tevékenységgel. A tizedik óra után a kísérletvezető unta el a dolgot, ö szakította meg a tevékenységet.

A helyváltoztatás, a felfedező tevékenység, a manipuláció tehát önmagában jutalmazó. Az újszerü, meglepő, összetett dolgok váltják ki leginkább a kíváncsiságot. Az új, ismeretlen ingerek és helyzetek érdeklődést és bizonytalanságot váltanak ki. Ez a belső állapot motiválja az explorációs viselkedést, amely az új ingerek jobb megértéséhez vezet (Berlyne, 1960).

A külvilág ingerei általános ébresztő hatást, aurosal növekedést gyakorolnak az agyra. Akinek alacsony a központi idegrendszeri aurosal szintje, az igényli, keresi az ingereket, fordított esetben kerüli. Az egyén adaptációs szintje határozza meg, milyen intenzitású vagy mennyiségü ingerhez szokott hozzá (Helson, 1948). Ez attól függ, hogy milyen környezetben él, mi a fő tevékenysége. Például, aki nagyvárosi környezetben él, vagy vég nélkül tévézik, zenét hallgat stb., azt nagyon sok inger éri, kellemetlen érzései, érzelmei alakulnak ki, ha tovább ingereljük a szervezetét. Ha fordított körülmények közé kerül, akkor viszont ingerkeresővé válik egy idő után.

$\mathrm{Az}$ adaptációs szinttől való bármely irányú eltérés valamilyen érzelmet kelt bennünk. Eleinte kedvező hatású az éberségi szint növelése az újszerü ingerekkel. Egyre nagyobb érdeklődést és pozitív érzelmeket élhetünk át. Majd, ha túlmegyünk az optimális szinten, az ismeretlen, szokatlan helyzet, vagy túlságosan változékony 
összetett inger támpontvesztést okozhat. Az újszerüség egy ponton túl szorongást, félelmet kelthet (Hunt, 1970).

Napjainkban a fiatalok többsége ingerözönben él. A reklámok, televízió, számítógép rendkívül változatos ingerhatásai mellett szinte állandósult a fülhallgatón keresztül történő zenehallgatás. Ez - a fentiek értelmében - a gyerekek adaptációs szintjét igen magasra emeli. A „hagyományos” tanóra egyszerübb - s nemegyszer kopottabb, szerényebb - ingereivel messze alulmaradhat a fiatalok által megszokott ingerlési szinttől. Nagy pedagógiai kihívás a diákok figyelmét lekötni és fenntartani ebben a helyzetben.

\section{Tudásszomj}

Berlyne (1960) fogalmi vagy konceptuális konfliktusnak nevezi a gondolati bizonytalanságot. Ilyen a kétség, a tanácstalanság, az ellentmondás, a fogalmi össze nem illés, összefüggéstelenség. Ez a belső feszültség belső késztetésként müködik, kíváncsiságot kelt és különféle viselkedésre sarkall. Mindez gyakorta egyfajta szóbeli aktivitáshoz vezet. Tehát aki valamit nem ért, nem tud, kérdéseket tesz fel, új összefüggéseket keres, hipotéziseket ellenőriz, gondolkodik. A fogalmi konfliktus feloldásának eszköze az információ, az ismeret, a tudás birtokba vétele. Így a tudás érték, tanuláselméleti értelemben megerősítő jelentőségü. Az ingerkereső viselkedés, a kíváncsiság hátterében a tudás megszerzésére irányuló motiváció áll. Mindenki ismeri, átérezte már azt az érzést, hogy minél többet tud egy témakörről, annál inkább érzi, tudja, hogy mennyi mindent kell még megtanulnia. A tudás hiányának átélése, a tényleges és a szükségszerủ tudás vagy ismeret közötti szakadék eltüntetése a cél (Loewenstein, 1994).

Litman (2005) az előbbi elméletet kiterjeszti. Azt fejti ki, hogy ha a tanulás, ismeretszerzés hátterében pusztán az ismerethiány eltüntetését látjuk, akkor a tanulás lényegében pusztán egyfajta menekülés lesz. Márpedig az, hogy ismereteket, információkat szerzünk, már maga pozitív érzéssel tölt el. Röviden: nemcsak a végeredmény fontos, hanem a folyamat, az ismeretszerzés maga is motivál. Ha élvezem a tanulást, jó benne lenni, szeretném, mert érdekel, akkor sokkal hatékonyabb a tanulás, mint amikor csak azért tanulok, mert valamilyen okból szükségem van a megszerzendő tudásra, vagy mert muszáj. Az idegélettani folyamatok is változnak aszerint, hogy miként állok a tanuláshoz. Amikor élvezem a tanulást magát, képalkotó eljárásokkal a nucleus accumbens opiát aktivizációja mutatható ki, ellenkező esetben pedig a mezolimbikus dopamin rendszer müködik föleg. Itt a folyamat végén elöálló jutalomnak van serkentő hatása. Ideális esetben a kettő együttmüködik, és a folyamat is élvezetes és a végeredmény is kecsegtető lehet számomra (Litman, 2005).

Személyfüggő, hogy ki mennyire élvezi, foglalja le magát erőfeszítést igénylő kognitív feladatokkal, tevékenységgel. A kognitív szükségletnek ezt az egyénre jellemző szintjét Cacioppo és Petty (Cacioppo és Petty, 1982) személyiségvonásként 
írják le. A magas kogníciószükségletü ember akkor is beleveti magát a tevékenységbe, amikor egyébként nem kényszerítik rá a körülmények. Ezek az emberek általában elégedettebbek az életükkel, mint az alacsony megismerési szükséglettel rendelkezők. A két csoport között viszont intellektusbeli különbséget nem találtak.

A vágy, szenvedély, kíváncsiság, érdeklődés érzései olyan erős akaraterőt váltanak ki az emberben, ami képessé tesz arra, hogy hatékonyak és kitartóak legyünk. A tudásvágy, az új ismeretek megszerzésére irányuló tevékenység pozitív érzelmeket vált ki, megelégedettséget okoz, ami további ismeretek megszerzésére motivál.

\section{Unalom}

Az unalom az egyik leggyötrőbb érzés. A kíváncsiság, a tudásszomj ilyenkor kielégítetlen. Nemcsak a szervezetet érő ingerek mennyiségétől, hanem minőségétől is függ az, hogy kellemesebben érezzük magunkat. A mai világban rendkívül sok, de feldolgozatlan, felületes inger ér bennünket. Gyakran nincs lehetőség, idő az ingerek érzelmi feldolgozására sem. Így aztán lehet, hogy ennek ellenére is kevésnek találjuk az ingerlést, az unalom érzését éljük át.

$\mathrm{Az}$, hogy mi áll az unalom hátterében, vitatott. Van, aki a figyelmi deficittel, torzult időérzékkel hozza kapcsolatba (Danckert és Allman, 2005). A motivációs megközelítés szerint viszont az unatkozó személynek az jelent problémát, hogy nem tudja elérni vagy elindítani azt a cselekvést, aktivitást, ami az ingeréhség kielégítéséhez kell. A körülményeket okolja az unalom érzése miatt, pedig a hiba a saját készülékében van. Nem képes saját érzelmeit kellőképpen megérteni, feldolgozni, tudatosítani. Analitikus megközelítés szerint azért vannak üresjáratai az unatkozó személynek, mert attól fél, hogy ha belső ingerléssel töltené ki ezeket, akkor felszínre kerülnének az elfojtott szexuális és agresszív tartalmak (Frischen et al., 2006). Az unalom pedig szorongáshoz, depresszióhoz, általában negatív hangulathoz, érzelmekhez vezet (Culp, 2006). Hatására a kíváncsiság, a tanulásra, felfedezésre való motivációnk is erejét veszti. Ha valaki sorozatosan azt éli át, hogy képtelen elérni a vágyott eredményt, elveszíti az érdeklődést.

\section{Következtetések}

Az affektív pszichológia - az érzelmi-motivációs tényezőkkel kiterjedten foglalkozó fellendülőben lévő tudományág - egyre nagyobb teret kap. Kutatási eredményei felhívják a figyelmet arra, hogy az érzelmek, affektusok mind gondosabb figyelembevétele és értő kezelése kiemelt fontossággal bír az élet minden területén, így az iskolák világában is. A tanulmányban összefoglaltak csupán néhány szempontot villantottak fel az affektív tényezők pedagógiában fontos hatásaival kapcsolatban. Rávilágítottak arra, hogy az affektív folyamatok és a velük szorosan összefüggö megismerésre irányuló motiváció az iskolai nevelés-oktatás minden területén sok- 
rétủ hatást fejt ki. Az érzelmi, hangulati hatások, az affektív stílus és a tartós személyiségvonások mind a tanárok, mind a diákok viselkedését és megismerő tevékenységét alapvetően befolyásolják. Az iskolai nevelés és oktatás tehát csak az affektív hatások ismeretében válhat hatékonnyá.

\section{Irodalom}

Ainsworth, M. (1982): Attachment: Retrospect and prospect. In: Parkers, C. M. - Stevenson-Hinde, J. (Eds.): The place of attachment in human behavior. Basic Books, New York, 3-30.

Ainsworth, M. D. S., Blehar, M. C., Waters, E., Wall, S. (1978): Patterns of attachment: A psychological study of the Strange Situation. Hillsdale, NJ, Erlbaum.

Atkinson, H., Smith E. E., Nolen-Hoeksema, S., Frederickson, B. L., Loftus G. R. (2005): Pszichológia. Osiris Kiadó, Budapest.

Atkinson R. L., Atkinson, R. C., Smith, E. E., Bem, D. J. (1995): Pszichológia. Osiris Kiadó, Budapest.

Bagdy Emőke (1994): Pedagógusszerepben. A szakmai önazonosság kialakulása, pályaszocializáció. In: Jávorka Gabriella - Libor Erika (szerk.): Tanári létkérdések. Raabe Kiadó, Budapest, 1.(1.).

Bányai Éva (2008): A hipnózis szociál - pszichobiológiai modellje. In: Bányai Éva - Benczúr Lilla (szerk.): A hipnózis és hipnoterápia alapjai. ELTE Eötvös Kiadó, Budapest, $379-445$.

Bányai Éva, Varga Katalin, Gősiné Greguss Anna (2001): Szuggesztív egyéniségek: Archaikus bevonódás tanárok és hipnotizőrök hatására. In: Pléh Csaba - László János Oláh Attila (szerk.): Tanulás, kezdeményezés, alkotás. ELTE Eötvös Kiadó, Budapest, 313-336.

Barkóczi Ilona, Putnoky Jenő (1980): Tanulás és motiváció. Tankönyvkiadó, Budapest.

Barkow, J. H., Cosmides, L., Tooby, J. (1991): The adapted mind: Evolutionary psychology and the generation of culture. Oxford University Press, Oxford.

Bartels, A., Zeki, S. (2004): The neural correlates of maternal and romantic love. Neuroimage, 21, 1155-1166.

Berlyne D. E. (1960): Conflict, arousal, and curiosity. McGraw-Hill Book Company, New York, Toronto, London.

Bower, G. H. (1981): Mood and memory. American Psychologist, (36) 2. 129-148.

Bowlby, J. (1969): Attachment and loss. (1) Attachment. Basic Books, New York.

Bowlby, J. (1979): The making and breaking of affectional bonds. Tavistock, London.

Buss, D. M. (1995/2001): Evolúciós pszichológia: új paradigma a pszichológia tudománya számára. In: Pléh Csaba - Csányi Vilmos - Bereczkei Tamás (szerk.): Lélek és evolúció. Az evolúciós szemlélet és a pszichológia. Osiris Kiadó, Budapest, 375-425.

Butler, R. (1958): The differential effect of visual and auditory incentives on the performance of monkeys. American Journal of Psychology, (71) 3, 591-593.

Butler, R. A. (1966): Curiosity in monkeys. In: Coopersmith, S. (Ed.): Frontiers of psychological research. Freeman and Co., San Francisco, 89-91. 
Cacioppo, J. T., Petty, R. E. (1982): The need for cognition. Journal of Personality and Social Psychology, (42) 1. 116-131.

Chaiken, S., Lieberman, E., Eagly, A. H. (1989): Heurastic and systematic information processing within and beyond the persuasion context. In: Uleman, J. S. - Bargh, J. A. (Eds.): Unintendend thought: Limits of awarenes, intention and control. Guilford, New York, 212-215.

Clark, M. S., Isen, A. M. (1982): Towards understanding the relationship between feeling staties and social behavior. In: Hastorf, A. H. - Isen, A. M. (Eds.): Cognitive social psychology. Elsevier-North Holland, New York, 73-108.

Cole, M., Cole, S. R. (1998): Fejlödéslélektan. Osiris Kiadó, Budapest.

Culp, N. A. (2006): The relations of two facets of boredom proneness with the major dimensions of personality. Personality and Differences, (41) 4, 999-1007.

Cserné Ádermann Gizella (1991): Az „önmagát beteljesítő jóslat” (Pygmalion-hatás) pedagógiai vizsgálata. In: Kósáné Ormai Vera (szerk.): A pedagógus. Neveléslélektan. $V$. Szöveggyüjtemény. Budapest, 162-173.

Damasio, A. R. (1996): Descartes tévedése. Aduprint, Budapest.

Danckert, J. A., Allman, A. A. (2005): Time flies when you're having fun: Temporal estimation and the experience of boredom. Brain and Cognition, (59) 3, 236-245.

Davidson R. J., Scherer K. R., Goldsmith H. H. (Eds., 2003): Handbook of affective sciences. Oxford University Press, Oxford.

Deci, E. L. (1971): Effects of external mediates rewards on intrinsic motivation. Journal of Personality and Social Psychology, (18) 1. 105-115.

Deci, E. L. (1975): Cognitive evaluation theory. In: Deci, E. L.: Intrinsic motivation. Plenum Press, New York, 129-159. Magyar nyelven: Deci, E. L. (1975b/1988): A kognitív értékelés elmélete. Az extrinzik jutalmak hatása az intrinzik motivációra. In: Barkóczi Ilona - Séra László (szerk.): Az emberi motiváció I-II. Tankönyvkiadó, Budapest, 333-360.

Deci, E. L. (1980): The psychology of self-determination. Lexington, MA. DC. Health.

Deci, E. L., Eghrari, H., Patrick, B. C., Leone, D. R. (1994): Facilitating internalization: The self-determination theory perspective. Journal of Personality, (62) 1, 119-142.

Deci, E. L., Koestner, R., Ryan, R. M. (1999): A meta-analytic review of experiments examining the effects of extrinsic rewards on intrinsic motivation. Psychological Bulletin, 125, 627-668.

Deci, E. L., Ryan, R. M. (1985): Intrinsic motivation and self-determination in human behavior. Plenum Publishing Co., New York.

Deci, E. L., Ryan, R. M. (1987): The support of autonomy and the control of behavior. Journal of Personality and Social Psychology, (53) 6, 1024-1037.

Deci, E. L., Ryan, R. M. (1990): A motivational approach to self: Integration in personality. In: Dientsbier, R. (Ed.): Nebraska Symposium on Motivation: 38. Perspectives on motivation. University of Nebraska Press, Lincoln, 237-288.

Deci, E. L., Ryan, R. M. (2000): The „what” and „why” of goal pursuits: Human needs and the self-determination of behavior. Psychological Inquiry, (11) 227-268. 
Field, T. M. (1985): In: Field, T. M. - Reite, M. (Eds.): The psychobiology of attachment and separation. Academic Press, New York, 415-416.

Forgács József (szerk., 2001): Érzelem és gondolkodás. Az érzelem szociálpszichológiája. Kairosz Kiadó, Budapest.

Forgas J. P. (Ed., 1991a): Emotion and social judgments. Pergamon Press, Oxford.

Forgas J. P. (1991b): Mood effects on partner choise: Role of affect in social decisions. Journal of Personality and Social Psychology, (61) 5, 708-720.

Forgas, J. P. (2001): Az érzelmek szerepe a gondolkodásban In: Forgács J. (szerk.): Érzelem és gondolkodás. Az érzelem szociálpszichológiája. Kairosz Kiadó, Budapest, 11-40.

Freud, S. (1923/1971): Az ősvalami és az én. In: Buda, Béla (szerk.): A pszichoanalizis és modern irányzatai. Gondolat Könyvkiadó, Budapest.

Frischen, A., Smilek, D., Reynolds, M. G., Gerritsen, C., Eastwood, J. D. (2006): Search for negative faces: Distinguishing between pre-attentive and post-attentive processes. Poster session presented at the 18th annual meeting of the Association for Psychological Science, New York, United States.

Gazzaniga, M. S. (Ed., 2000): New cognitive neurosciences. MIT Press, University of Chicago Press, Chicago.

Goleman, D. (1977): Érzelmi intelligencia. Háttér Kiadó, Budapest.

Grastyán Endre (1974/1988): Az emóció. In: Oláh Attila - Pléh Csaba (szerk.): Szöveggyüjtemény az általános és a személyiségpszichológiához. Pedagógia és tanárszakos hallgatók részére. Tankönyvkiadó, Budapest, 177-213.

Hamilton K., Waller, G. (1992): Media influences on body size estimation in anorexia and bulimia: an experimental study. The British Journal of Psychiatry, (162) 6, 837-840.

Harlow H. F. (1950): Learning and satiation of response in intrinsically motivated complex puzzle performance by monkeys. Journal of Comparative Physiology and Psychology, (43) 289-294.

Harlow, H. F. (1958): The Nature of Love. American Psychologist, (13) 673-685.

Harlow, H. F., Harlow, M. K., Meyer, D. R. (1950): Learning motivated by a manipulation drive. Journal of Experimental Psychology, (40) 2, 228-234.

Hazan, C., Shaver P. R. (1987): Romantic love conceptualized as an attachment process. Journal of Personality and Social Psychology, (52) 2, 511-524.

Helson H. (1948): Adaptation-level as a basis for a quantitative theory of frames of reference. Psychological Review, (55) 6, 297-313.

Hilgard, E. R. (1980): The trilogy of mind: cognition, affection, and conation. Journal of the History of Behavioral Sciences, (16) 107-117.

Holmes, D. S. (1974): Investigations of repression: Differential recall of material experimentally or naturally associated with ego threath. Psychological Bulletin, 81. 632-635.

Hovland C. I., Janis, L., Elley, H. H. (1973): A véleményváltozás kísérleti kutatásának öszszefoglalása. In: Hunyady György (szerk.): Szociálpszichológia. Gondolat, Budapest, 61-72.

Hunt, J. M. (1970): Toward a history of intrinsic motivation. In: Day, H. I. - Berlyne, D. E. Hunt, D. E. (eds.): Intrinsic motivation. Holt, Rienhart and Winston, Toronto, 1-32. 
Isen, A. M., Shalker, T., Clark, M., Karp, L. (1978): Affect, accessibility of material in memory, and behavior: A cognitive loop? Journal of Personality and Social Psychology, (36) 1-12. // magyarul: Clark M. - Isen, A. M. (1984): Az érzelmi állapotok és a szociális viselkedés közötti összefüggés feltárása felé. In: Hunyady György (szerk.): Szociálpszichológia. Gondolat Kiadó, Budapest, 580-636.

Kelman, H. C. (1973): A szociális befolyásolás három folyamata. In: Hunyady György (szerk.): Szociálpszichológia. Gondolat Kiadó, Budapest, 47-60.

Kissné Gombos Katalin (2008): Szuggesztív kommunikáció a pedagógiában. A szuggesztív tanár. Szakdolgozat, Debreceni Egyetem BTK, Pedagógia Szak.

Kraemer, G. W. (1992): A psychobiological theory of attachment. Behavioral and Brain Sciences, (15) 3. 493-541.

Kraemer, G. W., Clarke, A. S. (1990): The behavioral neurobiology of self-injurious behavior in rhesus monkeys. Progress in Neuro-psychopharmacology and Biological Psychiatry, (14) 141-168.

Litman, J. A. (2005): Curiosity and the pleasures of learning: Wanting and liking new information. Cognition and Emotion, (19) 6, 793-814.

Loewenstein, G. (1994): The Psychology of curiosity: A review and reinterpretation. Psychological Bulletin, (116) 1, 75-98.

Mayer, J. D., Salovey, P., Caruso, D. (2000): Models of emotional intelligence. In: Sternberg, R. J. (Ed.): The handbook of intelligence. Cambridge University Press, New York, 396-420.

Mérei Ferenc (1998): Közösségek rejtett hálózata. Osiris Kiadó, Budapest.

Mészáros István (1984): Hipnózis. Medicina Kiadó, Budapest.

Nash, M. R., Spinler, D. (1989): Hypnosis and tranference: A mesaure of archaic involvement. International Journal of Clinical and Experimental Hypnosis, (37) 129-144.

Neisser, U. (1967): Cognitive psychology. Appleton-Century-Crofts, New York.

Nissen, H. W. (1930): A study of exploratory behavior in the white rat by means of the obstruction method. Journal of Genetic Psychology, (37) 361-376.

Oatley, K., Jenkins, J. M. (2001): Érzelmeink. Osiris Kiadó, Budapest.

Panksepp, J. (2004): Affective neuroscience: The foundations of human and animal emotions. Oxford University Press, New York.

Pataki Ferenc (2004): Érzelem és identitás. Új Mandátum Könyvkiadó, Budapest.

Petty, R., Cacioppo, J. (1986): The elaboration likehood model of persuasion. In: Berkowitz (Ed.): Advances in experimental social psychology. Academic Press, New York, (19) 124-205.

Piaget, J. (1992): Az értelem pszichológiája. Gondolat Kiadó, Budapest.

Ryan, R. M., Deci, E. L. (2000): Self-determination theory and the facilitation of intrinsic motivation, social development, and well-being. American Psychologist, (55) 1, 68-78.

Shor, R. E. (1962/2008): A hipnózis mélységének három dimenziója. In: Bányai Éva Benczúr László (szerk.): A hipnózis és hipnoterápia alapjai. ELTE Eötvös Kiadó, Budapest, 203-216. 
Síklaki István, Terestyéni Tamás (szerk., 1988): Nyelv, kommunikáció, cselekvés I-II. Tankönyvkiadó, Budapest.

Spaulding, W. D. (Ed., 1994): Integrative view of motivation, cognition and emotion. Vol. 41 of the Nebraska symposium of motivation. University of Nebraska Press, Lincoln \& London.

Stroop, J. R. (1935): Studies of interference in serial verbal reactions. Journal of Experimental Psychology, (18) 6, 643-662.

Szabó Miklós (1987): A pedagógus Tolsztoj. Tankönyvkiadó, Budapest.

Ungárné Komoly Judit (1973): A tanitó személyiségének pedagógiai-pszichológiai vizsgálata. Akadémiai Kiadó, Budapest.

Urbán Róbert (2004): Érzelmek. In: N. Kollár Katalin - Szabó Éva (szerk.): Pszichológia pedagógusoknak. Osiris Kiadó, Budapest, 95-118.

Varga Katalin (szerk., 2008): Szuggesztív kommunikáció a szomatikus orvoslásban. VL Sugár Bt, Budapest.

Weiss, R. S. (1982): Attachment in adults. In: Parkers C. M. - Stevenson - Hinde, J. (Eds.): The place of attachment in human behavior. Basic Book, New York.

Weitzenhoffer, A. M.: (1989): The practise of hypnotism. John Wiley and Sons, Chichester.

Zeki, S. (2007): The neurobiology of love. Federation of European Biochemical Societies Letters, 2575-2579.

Zétényi Ágnes (2004): A tanár mint vezető, vezetői stílusok. In: Mészáros Aranka (szerk.): Az iskolai szociálpszichológia jelenségvilága. ELTE, Eötvös Kiadó, Budapest, 269-283. 